\title{
Aromatase activity in ovarian follicles of the golden hamster
}

\author{
P. L. Matson and W. P. Collins \\ Department of Obstetrics and Gynaecology, King's College Hospital Medical School, Denmark Hill, \\ London SE5 8RX, U.K.
}

\begin{abstract}
Summary. The aromatizing ability of recombined granulosa and thecal cells in culture, isolated from hamsters $72-78 \mathrm{~h}$ and $96-102 \mathrm{~h}$ after PMSG-stimulation, was assessed by the addition to the culture medium of androstenedione, testosterone, dehydroepiandrosterone (DHEA) or $5 \alpha$-dihydrotestosterone (DHT), and measuring the output of oestradiol $4 \mathrm{~h}$ later. The cells from all follicles taken after 96-102 $\mathrm{h}$ had a reduced oestradiol output compared to those isolated after 72-78 h $(P<0.02)$. Recombined cells from the unluteinized follicles at 96-102 h (Group I) showed similar oestradiol output in the presence of androstenedione, testosterone and DHEA to the cells from follicles taken at $72-78 \mathrm{~h}$. However, the recombined cells from the luteinized follicles (Group II) showed a reduced output of oestradiol in the presence of androstenedione, testosterone and DHEA when compared to the recombined cells from the previous period cultured with the corresponding $\mathrm{C}_{19}$ steroid. The results show that a reduced oestradiol output can be caused by (1) the reduced availability of aromatizable substrate and (2) a reduced potential aromatase activity.
\end{abstract}

\section{Introduction}

The gonadotrophin LH has been shown to bring about two time-related effects upon ovarian steroidogenesis; firstly there is an initial overall increase in steroid production which is followed by a decrease in oestradiol synthesis (Seamark, Moor \& McIntosh, 1974; Hillensjo, Bauminger \& Ahrèn, 1976). Various attempts have been made to identify the lesions which reduce the rate of conversion of $\mathrm{C}_{21}$-steroids to $\mathrm{C}_{18}$-steroids. The cleavage of $\mathrm{C} 21$-steroids by $\mathrm{C} 17-20$-lyase appears to be a major rate-limiting step (Lieberman et al., 1975; Matson, Gledhill \& Collins, 1984), thereby reducing the amount of aromatizable substrate available (Suzuki \& Tamaoki, 1980). However, a role for the aromatase enzyme system in regulating the production of oestradiol has also been suggested (Katz \& Armstrong, 1976; Hillier, van den Boogard, Reichert \& van Hall, 1980). There is also indirect evidence for the involvement of aromatase, because corpora lutea isolated from golden hamsters on Day 2 of the oestrous cycle are a potent source of androstenedione but not oestradiol (Terranova \& Greenwald, 1978).

The aim of this study was to investigate the reduction in endogenous oestrogen production by isolated follicular cells, and determine whether this is caused by the inhibition of the aromatase enzyme system, a reduction in the amount of aromatizable $\mathrm{C}_{19}$-substrate made available or a combination of the two. The use of PMSG-treated immature hamsters gives a large yield of follicles which have undergone the oestrogen-progestagen shift, and have been extensively described in terms of steroid content (Matson, Tyler \& Collins, 1981), morphology and pattern of steroid output in culture (Matson et al., 1984).

\section{Materials and Methods}

Animals. Details of the maintenance and injection of the animals were as described by Matson et al. (1981). Briefly, 25-day-old female golden hamsters (Mesocricetus auratus) were injected i.p. with 40 
i.u. PMSG. Animals were subsequently killed by injection of pentobarbitone sodium after $72-78 \mathrm{~h}$ $(\mathrm{N}=10)$ or $96-102 \mathrm{~h}(\mathrm{~N}=15)$. Heparinized blood was collected by cardiac puncture for progesterone estimation and those killed after $96-102 \mathrm{~h}$ were allocated to Group I (progesterone concentrations similar to those killed after $72-78 \mathrm{~h},<13.18 \mathrm{nmol} / \mathrm{l} ; \mathrm{N}=11$ ) or Group II (progesterone concentrations higher than those killed after $72-78 \mathrm{~h},>13.18 \mathrm{nmol} / \mathrm{l} ; \mathrm{N}=4$ ) (see Matson et al., 1984). Follicles from Group II animals showed morphological signs of luteinization but not rupture (Matson et al., 1984).

Tissue isolation and culture. The culture medium used throughout was Eagles Minimum Essential Medium (modified with Earle's salts) (Flow Laboratories Ltd, Irvine, U.K.) and supplemented with $10 \%$ fetal calf serum (Flow Laboratories Ltd), L-glutamine $(0.29 \mathrm{mg} / \mathrm{ml}$ ), sodium bicarbonate $(0.85 \mathrm{mg} / \mathrm{ml})$ and antibiotics (100 i.u. penicillin $/ \mathrm{ml} ; 50 \mu \mathrm{g}$ streptomycin $/ \mathrm{ml})$. Ovaries were removed immediately after death and placed directly into medium. Antral follicles $(591-740 \mu \mathrm{m})$ were then isolated and punctured, and the cells washed free of follicular fluid which contains large amounts of steroids (Matson et al., 1981) and could contaminate the medium. Recombined granulosa and thecal cells from individual follicles were then transferred to culture wells of 12-well multidishes (Linbro; Flow Laboratories Ltd) and cultured together for $4 \mathrm{~h}$ at $37^{\circ} \mathrm{C}$ in an atmosphere of $5 \% \mathrm{CO}_{2}$ in air and $100 \%$ humidity. The culture medium was hormone-free or contained $10^{-7} \mathrm{M}$-dehydroepiandrosterone, androstenedione, testosterone or $5 \alpha$-dihydrotestosterone. After this short culture period, aspirated medium was frozen at $-20^{\circ} \mathrm{C}$ until assayed for steroids.

Hormone determinations. The concentrations of plasma progesterone, and progesterone, androstenedione and oestradiol in the culture medium, were measured by radioimmunoassays (Matson et al., 1981, 1984).

Progesterone was assayed using an antiserum raised in a rabbit against progesterone-3carboxymethyloxime-BSA. The cross-reactions with closely related compounds (i.e. relative amount required to reduce the initial binding of $\left[{ }^{3} \mathrm{H}\right]$ progesterone by $50 \%$ were: $5 \alpha$ dihydroprogesterone $(14 \%), 17 \alpha$-hydroxyprogesterone $(0.5 \%), 20 \alpha$-dihydroprogesterone $(0.5 \%)$ and testosterone $(0.2 \%)$. The sensitivity was $0.0056 \mathrm{ng} /$ tube, the average recovery $90.7 \%$ and the mean bias $+6 \cdot 5 \%$ (over the range $0.5-10 \mathrm{ng} / \mathrm{ml}$ ). The intra- and inter-assay variations were both $<12 \%$ over 6 months.

Androstenedione was assayed using an antiserum raised in a rabbit against androstenedione$11 \alpha$-succinyl-BSA and cross-reacted with $11 \alpha$-hydroxyandrostenedione $(37 \%), 5 \alpha$-androstanedione $(29 \%), 5 \beta$-androstanedione $(8 \%), 6 \beta$-hydroxyandrostenedione $(0.7 \%)$, dehydroepiandrosterone $(0.6 \%)$ and androsterone $(0.5 \%)$. The sensitivity of the assay was $12.7 \mathrm{pg} /$ tube, the average recovery $77 \%$ and the mean bias $-8 \%$ (over the range $215 \cdot 3-1801 \cdot 1 \mathrm{pg} / \mathrm{ml}$ ). The intra-assay variation was $8.7 \%$ and the inter-assay variation $16.9 \%$ over 6 months.

The antiserum used in the oestradiol assay was raised in a rabbit against oestradiol-6carboxymethyloxime-BSA and cross-reacted with oestrone $(1.7 \%)$. The sensitivity of the assay was $3.9 \mathrm{pg} /$ tube, the average recovery $92 \%$ and the mean bias $-6.6 \%$ (over the range $300-3000 \mathrm{pg} / \mathrm{ml}$ ). The intra- and inter-assay variations were $<14 \%$ over 6 months.

Statistics. Group means and standard deviations were best represented by logarithmic transformations. Group data on steroid output were compared by the Mann-Whitney U test, with differences being considered significant if $P<0.05$.

\section{Results}

\section{Endogenous steroid output}

The output of progesterone, androstenedione and oestradiol by the recombined thecal and granulosa cells isolated 72-78 $\mathrm{h}$ and $96-102 \mathrm{~h}$ after PMSG administration is shown in Text-fig. 1. The cells from follicles recovered from all animals after 96-102 h (Groups I and II) showed similar 


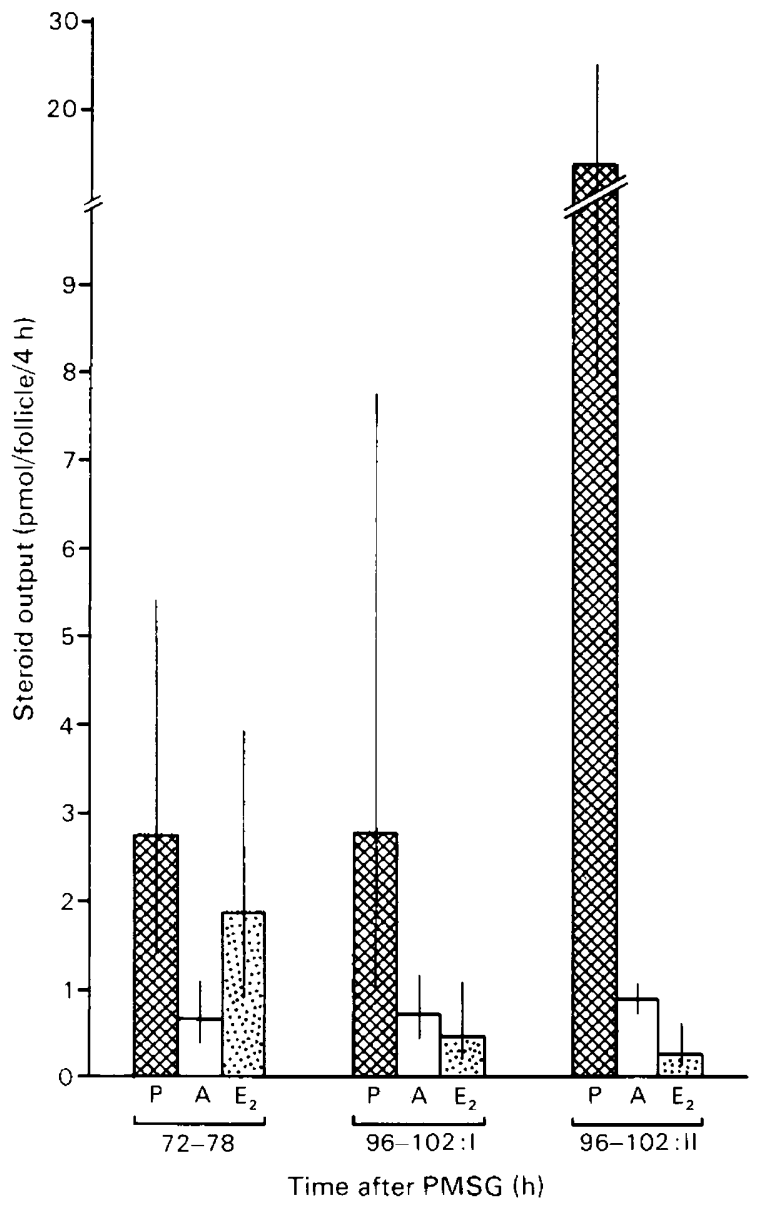

Text-fig. 1. The output of progesterone $(P)$, androstenedione $(A)$ and oestradiol $\left(E_{2}\right)$ by recombined thecal and granulosa cells from follicles isolated after 72-78 h and 96-102 $\mathrm{h}$ (Groups I and II). Values are geometric means and limits of 1 s.d. for 5-8 follicles.

reduced outputs of oestradiol $(P<0.02)$ when compared with the thecal and granulosa cells from follicles of the previous period. As expected, the recombined cells from Group II follicles were distinguished by an increased output of progesterone which was greater than that of those follicles taken at $72-78 \mathrm{~h}(P<0.002)$ or Group I after $96-102 \mathrm{~h}(P<0.02)$. No change was detected in the output of androstenedione.

\section{Potential aromatase activity}

The potential aromatase activity of the recombined thecal and granulosa cells was assessed by measuring the oestradiol output in the presence of various $\mathrm{C}_{19}$-steroid substrates, and the results are given in Table 1. Oestradiol output was significantly increased in the presence of dehydroepiandrosterone, androstenedione, or testosterone, but not dihydrotestosterone, when compared with corresponding control values obtained in hormone-free medium (all $P<0.05$ ). However, when the amount of oestradiol released into the medium was compared with that by recombined thecal and granulosa cells from follicles isolated before the reduction in endogenous oestradiol production, i.e. $72-78 \mathrm{~h}$ after the administration of PMSG, and incubated with the corresponding $\mathrm{C}_{19}$-steroid, only the recombined cells of follicles from Group I produced 
Table 1. The output of oestradiol by recombined thecal and granulosa cells from follicles $(591-740 \mu \mathrm{m})$ isolated $72-78 \mathrm{~h}$ and $96-102 \mathrm{~h}$ after PMSG administration and cultured in control medium or medium containing $10^{-7} \mathrm{M}$-androstenedione, testosterone, dehydroepiandrosterone or $5 \alpha$-dihydrotestosterone

\begin{tabular}{|c|c|c|}
\hline $\begin{array}{c}\text { Time after PMSG } \\
\text { (h) }\end{array}$ & Substrate & $\begin{array}{l}\text { Oestradiol production } \\
(\mathrm{pmol} / \text { follicle } / 4 \mathrm{~h})\end{array}$ \\
\hline \multirow[t]{5}{*}{$72-78$} & Control & $1.87(0.89-3.92)$ \\
\hline & Androstenedione & $6.44(4.89-8.85)^{*}$ \\
\hline & Testosterone & $5.27(3.19-8.70)^{*}$ \\
\hline & Dehydroepiandrosterone & $5.68(3.07-10.52)^{*}$ \\
\hline & $5 \alpha$-Dihydrotestosterone & $1.73(0.94-3 \cdot 18)$ \\
\hline \multirow[t]{5}{*}{ 96-102 (Group I) } & Control & $0.46(0.20-1.09) \dagger$ \\
\hline & Androstenedione & $3.68(1.28-10.58)^{*}$ \\
\hline & Testosterone & $7.48(3.17-17.67)^{*}$ \\
\hline & Dehydroepiandrosterone & $3.97(1.29-11.63)^{*}$ \\
\hline & $5 \alpha$-Dihydrotestosterone & $0.77(0.37-1.59) \dagger$ \\
\hline \multirow[t]{5}{*}{ 96-102 (Group II) } & Control & $0.25(0.11-0.61) \dagger$ \\
\hline & Androstenedione & $0.79(0.50-1.26)^{*} \dagger$ \\
\hline & Testosterone & $0.85(0.43-1.68)^{* \dagger}$ \\
\hline & Dehydroepiandrosterone & $0.70(0.34-1.46)^{*} \dagger$ \\
\hline & $5 \alpha$-Dihydrotestosterone & $0.24(0.13-0.46) \dagger$ \\
\hline
\end{tabular}

Values are geometric means and limits of 1 s.d. for 5 replicates.

* Significantly different from control culture, $P<0.05$.

$\uparrow$ Significantly different from recombined cells of follicles isolated after 72-78 h and cultured with corresponding $\mathrm{C}_{19}$-steroid, $P<0.05$.

comparable amounts, with those from Group II producing significantly reduced quantities (all $P<0.05)$.

It therefore appears that the recombined thecal and granulosa cells from all follicles isolated after 96-102 h show reduced endogenous output of oestradiol, with those follicles in Group II showing reduced potential aromatase activity.

\section{Discussion}

The measurement of steroids produced by follicles and released into follicular fluid in vivo (Baird, 1977) or culture medium in vitro (Dorrington, 1977) has confirmed that there is a reduction of oestradiol synthesis by the follicle after exposure to $\mathrm{LH}$, which is mirrored by that of the $\mathrm{C}_{19^{-}}$steroids (Lieberman et al., 1975; Katz \& Armstrong, 1976). The reduced rate of oestradiol synthesis can be a consequence of a reduced availability of $\mathrm{C}_{19}$-steroid substrate, as demonstrated by the administration of exogenous testosterone to intact animals (Katz, Leung \& Armstrong, 1979; Suzuki \& Tamaoki, 1980) or follicles in culture (Hillensjo, Hamberger \& Ahrèn, 1977). Such a situation occurred in the present study with the follicles isolated after 96-102 $\mathrm{h}$ and assigned to Group I, because the amount of oestradiol produced in the presence of exogenous aromatizable substrate was similar to that of the previous time period, despite a reduction in the de-novo synthesis of oestradiol by freshly dissected follicles maintained in control medium. On the other hand, the data from follicles of Group II clearly demonstrate that the luteinized tissue in this series of animals (Matson et al., 1984) has a markedly reduced potential aromatase activity. This is similar to the findings of Henderson \& Moon (1979) who showed that the formation of bovine corpora lutea was associated with a progressive decline in aromatase activity. Also, newly formed corpora lutea of the golden hamster have reduced aromatizing capacity when compared to follicles of prooestrous animals (Terranova, 1981). However, the aromatase activity of whole follicles (Terranova, 1981) and granulosa cells (Terranova, Martin \& Chien, 1982) of the hamster in which ovulation is 
delayed by phenobarbitone is increased during the first 2 days of delay. The loss of aromatizing ability has been attributed to three possible mechanisms. Firstly, Hillier et al. (1980) have shown that the naturally occurring non-aromatizable $5 \alpha$-reduced $\mathrm{C}_{19}$-steroids, $5 \alpha$-dihydrotestosterone and $5 \alpha$-androstanedione, are potent competitive inhibitors of the granulosa cell aromatase reaction in vitro. Therefore, there may well be a reciprocal relationship between $5 \alpha$-reductase and aromatase activity in the regulation of ovarian oestrogen synthesis (Siiteri \& Thompson, 1975). Secondly, an LH-induced inhibition of the aromatase enzyme system of a non-competitive type in rat follicles has been described by Katz \& Armstrong (1976), although they were unable to determine whether the inhibition was mediated via steroids or other secondary inhibitory agents. Thirdly, the fall in $\mathrm{C}_{19}$-steroid production, occurring at the same time as the fall in oestradiol synthesis, results in a decrease in the amount of aromatase present. This is supported by the observation of Katz et al. (1979) that the administration of high levels of exogenous testosterone to rats pretreated with an inhibitor of $\mathrm{C} 17-20$-lyase reduces the subsequent drop in aromatase activity, which suggests that testosterone, in addition to serving as a substrate for $\mathrm{C}_{18}$-steroid synthesis, may also have a role in the maintenance of the aromatase enzyme system.

In conclusion, the present study has demonstrated that a reduction in the endogenous production of oestradiol by recombined thecal and granulosa cells of the hamster may be caused both by the reduced availability of aromatizable substrate and the loss of potential aromatase activity. It is therefore proposed that the luteinization of hamster follicles involves a combination of these two mechanisms, with the inhibition of the C17-20-lyase enzyme being followed by the loss of potential aromatase activity.

\section{References}

Baird, D.T. (1977) Synthesis and secretion of steroid hormones by the ovary in-vivo. In The Ovary, 2nd edn, Vol. III, pp. 305-357. Eds S. Zuckerman \& B. J. Weir. Academic Press, New York.

Dorrington, J.H. (1977) Steroidogenesis in-vitro. In The Ovary, 2nd edn, Vol. III, pp. 359-412. Eds S. Zuckerman \& B. J. Weir. Academic Press, New York.

Henderson, K.M. \& Moon, Y.S. (1979) Luteinization of bovine granulosa cells and corpus luteum formation is associated with loss of aromatizing ability. $J$. Reprod. Fert. 56, 89-97.

Hillensjo, T., Bauminger, S. \& Ahrèn, K. (1976) Effect of luteinizing hormone on the pattern of steroid production by preovulatory follicles of pregnant mare's serum gonadotropin-injected immature rats. Endocrinology 99, 996-1002.

Hillensjo, T., Hamberger, L. \& Ahrèn, K. (1977) Effect of androgens on the biosynthesis of oestradiol-17 $\beta$ by isolated periovulatory rat follicles. Molec. cell. Endocr. 9, 183-193.

Hillier, S.G., van den Boogard, A.M.J., Reichert, L.E., Jr \& van Hall, E.V. (1980) Alterations in granulosa cell aromatase activity accompanying preovulatory follicular development in the rat ovary with evidence that $5 \alpha$-reduced C19-steroids inhibit the aromatase reaction in vitro. J. Endocr. 84, 409-419.

Katz, Y. \& Armstrong, D.T. (1976) Inhibition of ovarian estradiol-17 73 secretion by luteinizing hormone in prepubertal, pregnant mare serum-treated rats. Endocrinology 99, 1442-1447.

Katz, Y., Leung, P.C.K. \& Armstrong, D.T. (1979) Testosterone restores ovarian aromatase activity in rats treated with a 17,20-lyase inhibitor. Molec. cell. Endocr. 14, 37-44.
Lieberman, M.E., Barnea, A., Bauminger, S., Tsafriri, A., Collins, W.P. \& Lindner, H.R. (1975) LH effect on the pattern of steroidogenesis in cultured Graafian follicles of the rat: dependence on macromolecular synthesis. Endocrinology 96, 1533-1542.

Matson, P.L., Tyler, J.P.P. \& Collins, W.P. (1981) Follicular steroid content and oocyte meiotic status after PMSG stimulation of immature hamsters. $J$. Reprod. Fert. 61, 443-452.

Matson, P.L., Gledhill, B. \& Collins, W.P. (1984) The effect of LH on steroidogenesis by hamster follicles isolated at defined stages of development. J. Reprod. Fert. 70, 675-681.

Seamark, R.F., Moor, R.M. \& McIntosh, J.E.A. (1974) Steroid hormone production by sheep follicles cultured in vitro. J. Reprod. Fert. 41, 143-158.

Siiteri, P.K. \& Thompson, E.A. (1975) Studies of human placental aromatase. J. Steroid Biochem. 6, 317-322.

Suzuki, K. \& Tamaoki, B. (1980) Postovulatory decrease in estrogen production is caused by the diminished supply of aromatizable androgens to ovarian aromatase. Endocrinology 107, 2115-2116.

Terranova, P.F. (1981) Steroidogenesis in experimentally induced atretic follicles of the hamster: a shift from estradiol to progesterone synthesis. Endocrinology 108, 1885-1890.

Terranova, P.F. \& Greenwald, G.S. (1978) Steroid and gonadotropin levels during the luteal-follicular shift of the cyclic hamster. Biol. Reprod. 18, 170-175.

Terranova, P.F., Martin, N.C. \& Chien, S. (1982) Theca is the source of progesterone in experimentally induced atretic follicles of the hamster. Biol. Reprod. 26, 721727.

Received 9 January 1984 